\title{
Peertechz
}

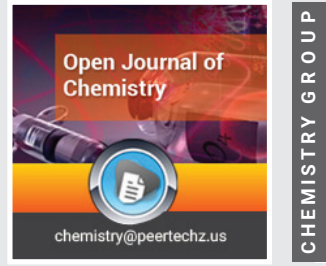

\section{Chemical and physical stability of selected drugs for aerosol therapy with Sirmione thermal}

\section{water}

\section{Francesco Saverio Robustelli della Cuna ${ }^{1,2 *}$, Carlo Sturani ${ }^{3}$, Sarah Galfrè ${ }^{1}$, Luisa Gervasio ${ }^{2}$, Cristina Sottani ${ }^{4}$ and Elena} Grignani $^{4}$

${ }^{1}$ Department of Drug Sciences, University of Pavia, Italy

${ }^{2}$ Casimiro Mondino National Neurological Institute, Pavia, Italy

${ }^{3}$ Terme di Sirmione, Colombare di Sirmione, (BS), Italy

${ }^{4}$ Environmental Research Center, ICS Maugeri SPA SB, Institute of Pavia, IRCCS, Via Salvatore Maugeri, 10-27100 Pavia (PV), Italy
Received: 29 June, 2021

Accepted: 09 July, 2021

Published: 10 July, 2021
*Corresponding authors: Francesco Saverio Robustelli della Cuna, Department of Drug Sciences, University of Pavia, Casimiro Mondino Neurological Institute Foundation, Via Mondino, 2, 27100 Pavia, Italy, Tel: +39-3823801; Fax: +39-382-3801;

E-mail: fsaveriorobustelli@unipv.it

ORCID: https://orcid.org/0000-0003-3895-7978

Keywords: Sirmione thermal water; Ambroxol; Beclomethasone dipropionate; Budesonide; $\mathrm{N}$-acetylcysteine; Stability

https://www.peertechzpublications.com

\section{Check for updates}

\section{Abstract}

In this work, we investigated the chemical and physical stability of ambroxol, beclomethasone dipropionate, budesonide and $\mathrm{N}$-acetylcysteine after dilution with Sirmione thermal water, stored in ampoules for aerosol, at room temperature. The chemical stability of all active drugs was evaluated by Ultra-High-Performance Liquid Chromatography tandem mass spectrometry (UHPLC/MS/MS). All samples were analyzed in triplicate at room temperature under normal fluorescent light at $0 \mathrm{~h}, 1 \mathrm{~h}, 6 \mathrm{~h}$, $12 \mathrm{~h}$, and $24 \mathrm{~h}$. According to the Official Pharmacopoeia of the Italian Republic, the degradation of a molecule that exceeds more than $10 \%$ is considered unacceptable. After dilution with thermal water of Sirmione, ambroxol, beclomethasone dipropionate, budesonide, and $\mathrm{N}$-acetylcysteine, were found to be physically stable over the entire study (degradation $<3 \%$ ) at room temperature without any loss of activity.

\section{Introduction}

Respiratory diseases represent an important public and private expense. However, the impact is not only economic, but other factors must be considered: in pediatric patients, diseases such as rhinosinusitis, rhinitis, asthma, and upper and lower respiratory tract infections have extremely relevant social and clinical implications. In Italy, a quarter of the medical consultations relating to primary care in pediatric patients concern respiratory problems [1]. The airway allows the medication to arrive directly at the nasal fossa without systemic distribution, with a high therapeutic effect and low undesirable effects [2-4]. The most-commonly prescribed nebulizers for the treatment of upper and middle respiratory tract diseases are corticosteroids, mucolytics agents, and antibiotics [5-7]. In order to improve the drug administration, the molecules were mingled with $0.9 \%$ or $3 \%$ sodium chloride solutions and subsequently administered via aerosol. The use of these sodium chloride solutions enhances not only the inhaled drug's permeability and bioavailability [8], but also the therapeutic effect, leading to the improvement of the mucociliary clearance time [9]. Currently, in common clinical practice, Sirmione thermal water is also used as a diluent, especially for mucolytic agents and corticosteroids. Because of the high concentration of sodium chloride, carbonates and calcium salts, the saltybromine-iodine thermal water of Sirmione exhibits hypertonic properties that lead to a fluidifying and cleansing action (Table 1). 
Table 1: Chemical composition of Sirmione Thermal Water ${ }^{\oplus}$, (Regional agency for prevention, environment, and energy (ARPAE), Reggio Emilia, Italy, 2020).

\begin{tabular}{|c|c|c|}
\hline pH & & 6.7 \\
\hline Conductivity & $\mathrm{\mu s} / \mathrm{cm}$ & 3870 \\
\hline Fixed residue at $180^{\circ} \mathrm{C}$ & $\mathrm{mg} / \mathrm{L}$ & 2500 \\
\hline Chlorides $(\mathrm{Cl})$ & $\mathrm{mg} / \mathrm{L}$ & 1120 \\
\hline Sodium $(\mathrm{Na})$ & $\mathrm{mg} / \mathrm{L}$ & 650 \\
\hline Bicarbonates $\left(\mathrm{HCO}_{3}\right)$ & $\mathrm{mg} / \mathrm{L}$ & 318 \\
\hline Calcium $(\mathrm{Ca})$ & $\mathrm{mg} / \mathrm{L}$ & 196 \\
\hline Sulfate $\left(\mathrm{SO}_{4}\right)$ & $\mathrm{mg} / \mathrm{L}$ & 156 \\
\hline Silica $\left(\mathrm{SiO}_{2}\right)$ & $\mathrm{mg} / \mathrm{L}$ & 55.5 \\
\hline Potassium $(\mathrm{K})$ & $\mathrm{mg} / \mathrm{L}$ & 32.2 \\
\hline Magnesium $(\mathrm{Mg})$ & $\mathrm{mg} / \mathrm{L}$ & 31.8 \\
\hline Hydrogen sulfide $\left(\mathrm{H}_{2} \mathrm{~S}\right)$ & $\mathrm{mg} / \mathrm{L}$ & 13.6 \\
\hline Bromides $(\mathrm{Br})$ & $\mathrm{mg} / \mathrm{L}$ & 5.6 \\
\hline Fluorides $(\mathrm{F})$ & $\mathrm{mg} / \mathrm{L}$ & 4.2 \\
\hline Ammonia $\left(\mathrm{NH}_{4}\right)$ & $\mathrm{mg} / \mathrm{L}$ & 2.0 \\
\hline Nitrates $\left(\mathrm{NO}_{3}\right)$ & $\mathrm{mg} / \mathrm{L}$ & $<1$ \\
\hline Iodine $(\mathrm{I})$ & $\mathrm{mg} / \mathrm{L}$ & 0.5 \\
\hline Nitrites $\left(\mathrm{NO}_{2}\right)$ & $\mathrm{mg} / \mathrm{L}$ & $<0.002$ \\
\hline
\end{tabular}

The water of Sirmione has an adjuvant action in the treatment of both infectious and allergic rhinitis and sinusitis thanks to: a) its mucolytic and unblocking action, due to the sulfur content, especially present as hydrogen sulfide, moreover, it has a vasodilating and stimulating action on the secretory IgA of the nasal mucus and it can improve the rheological characteristics of the mucus, b) its antiseptic action, due to iodine content, c) its moisturizing action, due to the mineral complex [10]. These properties make the thermal water of Sirmione suitable not only for aerosol therapy, but it can also be used as a diluent for active drugs for inhalation use. This study aims to evaluate the stability in aerosol containers of two mucolytic agents, N-acetylcysteine (300 $\mathrm{mg} / 3 \mathrm{ml}$ ) and ambroxol (15 mg $/ 2 \mathrm{ml})$, and two corticosteroids beclomethasone dipropionate $(800 \mu \mathrm{g} / 2 \mathrm{ml})$ and budesonide ( $0.50 \mathrm{mg} / 2 \mathrm{ml}$ and $0.25 \mathrm{mg} / 2 \mathrm{ml}$ ), after dilution with Sirmione thermal water stored in plastic ampoules, for aerosol therapy. A large number of analytical methods for the determination and quantification of N-acetylcysteine [11,12], ambroxol [13,14], budesonide [15] and beclomethasone dipropionate [16,17] in pharmaceutical preparations have been developed. However, in spite of the structural diversity and different chemical-physical properties of these drugs (Figure 1), mainly due to the presence of excipients (sodium edetate, polysorbate 80 , polysorbate 20 , and sorbitan laurate) that can interfere with the separation process, no method was found for their simultaneous analysis. Ultra-high-performance liquid chromatography-tandem mass spectrometry (UHPLC-MS/MS) allowed the optimization of the method and the separation of the four drug in a short analysis time.

\section{Materials and methods}

\section{Chemicals}

For chromatography, acetonitrile, formic acid, and ammonium formate solution in LC-MS-grade water (Merck House, Poole, UK) were used. Other organic solvents (i.e. methanol) were purchased from Merck (KGa A64271 Darmstadt, Germany). Analytical-grade N-acetylcysteine, ambroxol, beclomethasone diproprionate, and budesonide powder used for validation and quality control of the UHPLC/ MS/MS assay were purchased from Ultra scientific, Bologna, Italy. Commercially available formulations were employed to prepare the solutions in aerosol ampoule (Meds Neosol ampoule, Farmac Zabban, Calderara Di Reno, Italy, lot 201808).

Ambroxol (Fluibron ${ }^{\circledR}(15 \mathrm{mg} / 2 \mathrm{ml})$ was purchased from Chiesi Farmaceutici S.p.A, Parma, Italy, lot1099365). Beclometasone dipropionate (Clenil ${ }^{\circledast}(800 \mu \mathrm{g} / 2 \mathrm{ml})$ was purchased from Chiesi Farmaceutici S.p.A, Parma, Italy, lot1094230). Budesonide (Aircort $^{\circledR}(0.25 \mathrm{mg} / 2 \mathrm{ml}$ and $0.50 \mathrm{mg} / 2 \mathrm{ml})$ was purchased from Italchimici S.p.A., Pomezia, Italy, lot 055119. N-acetylcysteine (Fluimucil $^{\circledR}(300 \mathrm{mg} / 3 \mathrm{ml})$ was purchased from Farma 1000 S.r.l., Milan, Italy, lot FL9072a), Thermal water of Sirmione in multidose dose vials (Acqua di Sirmione ${ }^{\circledR}$ ) was purchased from Terme di Sirmione, Sirmione, Italy, lot 0154A).

\section{Sample preparation}

Triplicate samples of tested drugs were analyzed immediately after dilution with thermal water of Sirmione (final volume $5 \mathrm{ml}$ ) at 1 hour, 6 hours, 12 hours and 24 hours. Samples were stored in aerosol ampoules at room temperature and exposed to normal fluorescent light. The final concentration of the solutions obtained were $30 \mathrm{mg} / \mathrm{ml}$ for ambroxol, 0.16 $\mathrm{mg} / \mathrm{ml}$ for beclomethasone dipropionate, $0.05 \mathrm{mg} / \mathrm{ml}$ and 0.10 $\mathrm{mg} / \mathrm{ml}$ for budesonide and $60 \mathrm{mg} / \mathrm{ml}$ for $\mathrm{N}$-acetylcysteine, respectively. To avoid the solvent's evaporation, the aerosol ampoules were sealed with Parafilm ${ }^{\circledR}$. The $\mathrm{pH}$ of the solutions was determined before each analysis using a pH meter (HBasic 20, Crison Instruments S.p.A., Modena, Italy). Analyzes were performed in triplicate $(\mathrm{n}=45)$. The $\mathrm{pH}$ was measured immediately after dilution with thermal water of Sirmione at 1 hour, 6 hours, 12 hours and 24. The sterility of the samples was not assessed.<smiles>CC(=O)N[C@@H](CS)C(=O)O</smiles>

A<smiles>Nc1c(Br)cc(Br)cc1CNC1CCC(O)CC1</smiles>

B

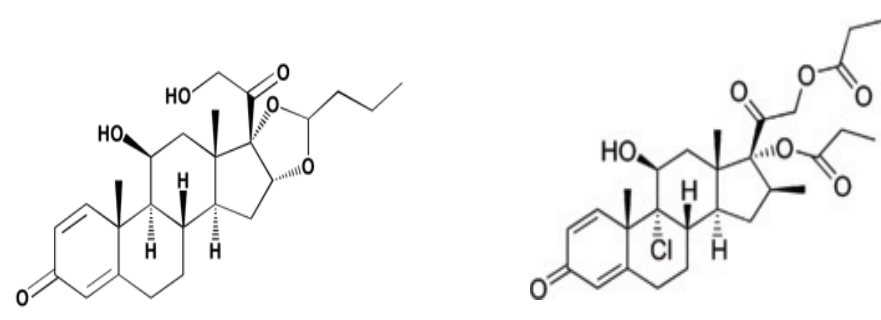

Figure 1: Chemical structure of N-acetylcysteine (A), ambroxol (B), Budesonide (C) and beclomethasone dipropionate (D).

Citation: Robustelli della Cuna FS, Sturani C, Galfrè S, Gervasio L, Grignani E, et al. (2021) Chemical and physical stability of selected drugs for aerosol therapy with Sirmione thermal water. Open Journal of Chemistry 7(1): 029-033. DOI: https://dx.doi.org/10.17352/ojc.000026 


\section{Quantitative analysis using UHPLC/MS/MS}

The UHPLC system consisted of an Agilent Technologies 1200 series system equipped with a degasser, binary pump and a high-performance autosampler (HiP ALS SL+) with a thermostatic column compartment. Separation was carried out using a reversed-phase Zorbax Eclipse Plus, $2.1 \times 100 \mathrm{~mm}, 1.8$ $\mu \mathrm{m}$ (Agilent, Santa Clara, CA, USA), operating at $0.3 \mathrm{ml} / \mathrm{min}$. The mobile phase consisted of $10 \mathrm{mM}$ ammonium formate/ formic acid $0.1 \%$ in acetonitrile $80: 20(\mathrm{v} / \mathrm{v})$ as solvent $\mathrm{A}$ and $10 \mathrm{mM}$ ammonium formate/formic acid $0.1 \%$ in acetonitrile 20:80 (v/v) as solvent B. The initial conditions were $95 \% \mathrm{~A}$ and $5 \% \mathrm{~B}$. The mobile phase B linear gradient was applied as follows: mobile phase B ( $5 \%$ ) was held for $2 \mathrm{~min}$, then it was increased to $95 \%$ in $6.0 \mathrm{~min}$ and held at this percentage for $0.5 \mathrm{~min}$. This procedure was followed by the reconstitution of starting conditions within $0.1 \mathrm{~min}$, and by the equilibration with $5 \%$ of $\mathrm{B}$ for $0.5 \mathrm{~min}$, resulting in a total analysis time of $11 \mathrm{~min}$. UHPLC flow rate was set at $400 \mu \mathrm{L} / \mathrm{min}$ and the column temperature at $40{ }^{\circ} \mathrm{C}$.The injection volume was $5 \mu \mathrm{l}$. The analysis was performed with the UHPLC tandem 6460 triple quadrupole mass spectrometer (Agilent Technologies, Inc.). An Agilent Mass Hunter workstation was used for the control of equipment, data acquisition, and analysis. The 6460 Agilent featuring an electro- spray ionization (ESI) interface served for MS/MS analysis. The source operated with the Jet Stream technology and a super-heated sheath gas helped to enhance sensitivity. The ion source parameters for negative mode were as follows: vaporizer temperature, $250{ }^{\circ} \mathrm{C}$; sheath gas, $11 \mathrm{~mL} /$ min; temperature, $250{ }^{\circ} \mathrm{C}$; nozzle voltage, $400 \mathrm{~V}$ and capillary voltage, 3000 V. Finally, nitrogen was used as nebulizer gas and was set at 45 psi with a flow rate of $5 \mathrm{~L} / \mathrm{min}$.

\section{Data analysis}

The initial concentration was considered as $100 \%$ and the subsequent concentrations were expressed as a percentage of the initial value. Following the acceptability criteria indicated by the Official Italian Pharmacopoeia, the degradation of a molecule greater than $10 \%$ of the initial concentration is considered unacceptable in terms of loss of activity [18]. The accuracy and precision of our assay met standards set for bioanalytical method validation [19].

\section{Results and discussion}

The development of the analytical method allowed the simultaneous analysis of the four different drugs with a total analysis time of 11 minutes. In this study, a triple quadrupole mass spectrometer was used as a detector that allowed the optimization of the mass transitions of the individual compounds. In particular, the following selected reaction monitoring (SRM) transitions were used: N-acetylcysteine $164 \rightarrow 59$, ambroxol $376 \rightarrow 261$, budesonide $521 \rightarrow 503$, and beclomethasone dipropionate $431 \rightarrow 413$. Figure 2 shows the separation of the analytes in the Total Ion Chromatogram (TIC).

The method was found to be linear in concentrations between 500-5000 $\mathrm{ng} / \mathrm{ml}$ for ambroxol, budesonide and beclomethasone dipropionate $\left(r^{2}=0.9975,0.9964\right.$ and 0.9975 , respectively) and between $50-500 \mathrm{ng} / \mathrm{ml}$ for $\mathrm{N}$-acetylcysteine

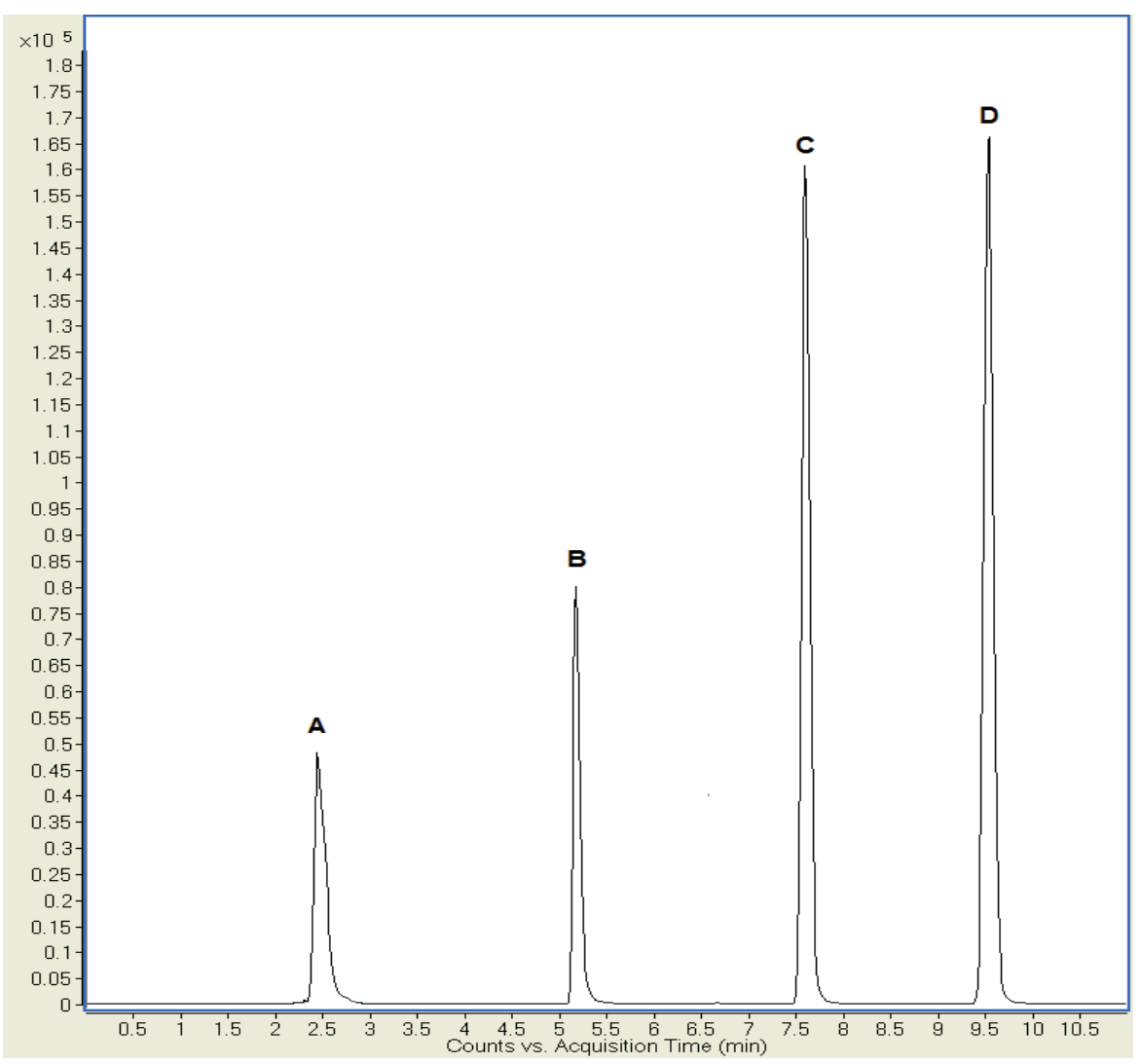


$\left(r^{2}=0.9962\right)$. Peak areas were used for the determination of the different drug concentrations. The coefficients of regression $\left(r^{2}\right)$ for all of the standard curves were found to be between 0.98 and 0.99 , during the whole study. Intraday and interday coefficients of variation for acetylcysteine samples were ranked from $<6 \%$ at $80 \mu \mathrm{g} / \mathrm{mL}$ to $<2 \%$ at $220 \mu \mathrm{g} / \mathrm{mL}$. Table 1 shows the stability data of the four molecules analyzed in aerosol ampoules at room temperature under light exposure, after dilution with Sirmione thermal water. As we can see in Table 2, all drugs exhibited optimal stability at +1 hours, +6 hours, +12 hours, and +24 hours.

The average percentage of degradation found for each molecule was: $0.3 \%$ for $\mathrm{N}$-acetylcysteine, $0.6 \%$ for ambroxol,

Table 2: Stability of ambroxol, beclomethasone dipropionate, budesonide, and $\mathrm{N}$-acetylcysteine in aerosol ampoules after dilution with Sirmione thermal water.

\begin{tabular}{|c|c|c|c|c|c|}
\hline Active drug & $\begin{array}{c}\text { Actual initial } \\
\text { concentration } \\
(\mathbf{m g} / \mathrm{mL})\end{array}$ & \multicolumn{3}{|c|}{$\%$} \\
\hline & +1 hour & +6 hours & +12 hours & $\mathbf{+ 2 4 h o u r s}$ \\
\hline Ambroxol & $3.0 \pm 0.4$ & $99.6 \pm 0.3$ & $100.0 \pm 0.3$ & $99.9 \pm 0.4$ & $98.1 \pm 0.4$ \\
\hline $\begin{array}{c}\text { Beclomethasone } \\
\text { dipropionate }\end{array}$ & $0.16 \pm 0.3$ & $100.1 \pm 0.3$ & $99.8 \pm 0.3$ & $99.7 \pm 0.1$ & $99.6 \pm 0.3$ \\
\hline Budesonide & $0.05 \pm 0.2$ & $99.8 \pm 0.2$ & $99.9 \pm 0.3$ & $99.7 \pm 0.2$ & $97.8 \pm 0.1$ \\
\hline Budesonide & $0.1 \pm 0.5$ & $99.9 \pm 0.3$ & $99.8 \pm 0.2$ & $99.6 \pm 0.3$ & $98.8 \pm 0.5$ \\
\hline N-acetylcysteine & $60 \pm 0.2$ & $99.9 \pm 0.3$ & $99.5 \pm 0.4$ & $99.6 \pm 0.3$ & $99.8 \pm 0.2$ \\
\hline
\end{tabular}

aMean \pm S.D. of three samples tested in triplicates.
$0.7 \%$ for budesonide $(0.25 \mathrm{mg} / \mathrm{ml}), 0.5 \%$ for budesonide $(0.50 \mathrm{mg} / \mathrm{ml})$ and $0.2 \%$ for beclomethasone dipropionate. All solutions had a pH of $6.82+0.4$ for the entire study. UHPLC belongs to a new category of separative techniques based on established principles of liquid chromatography. The stationary phase is composed by particles smaller than $2 \mu \mathrm{m}$. Furthermore, the mobile phase can operate at high speeds and this positively influences the resolution, sensitivity, and speed of the analysis. Due to its speed and sensitivity, this technique has gained considerable attention in recent years in the field of pharmaceutical and biomedical analysis [20]. A large number of factors can affect the stability of a pharmaceutical product, that includes manufacturing process, stability of the molecule, storage conditions (temperature, exposure to light and humidity), as well as chemical reactions such as oxidation, reduction, hydrolysis, and racemization, which could occur after dilution of the drug before administration. The analyses carried out allowed not only the determination of the stability of the four drugs studied, but also the exclusion of degradation products, and impurities already known in literature for all tested drugs [12,15,16,21] (Figure 3).

\section{Conclusion}

The proposed method was successfully developed and allowed to define an efficient, simple, rapid, sensitive, and economical protocol for the evaluation of the stability of ambroxol (15 mg/2ml), beclomethasone dipropionate (800 $\mu \mathrm{g} / 2 \mathrm{ml})$, budesonide $(0.50 \mathrm{mg} / 2 \mathrm{ml}$ and $0.25 \mathrm{mg} / 2 \mathrm{ml})$ and

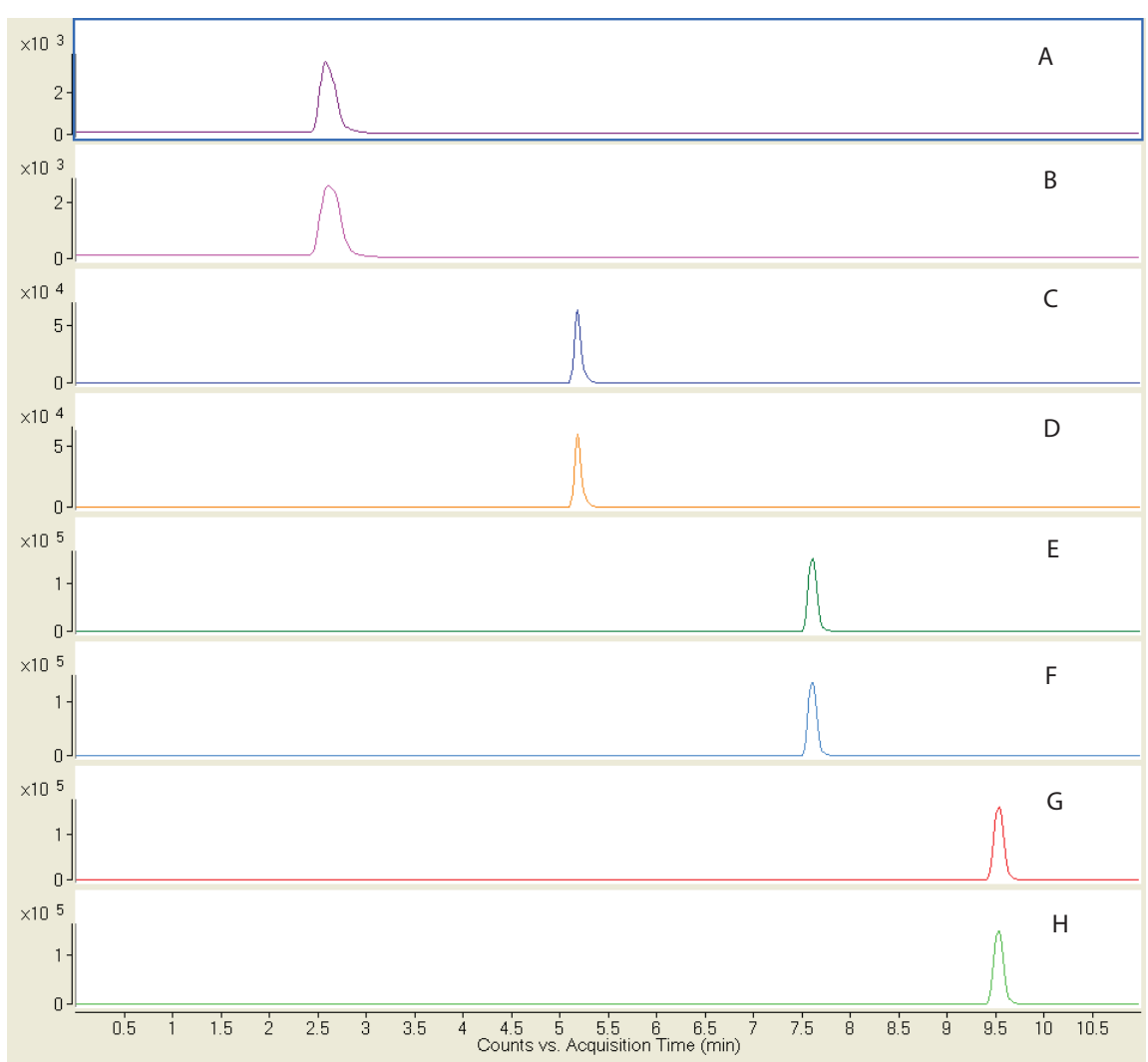

Figure 3: Chromatographic profile (SRM) for $\mathrm{N}$-acetylcysteine transition $164 \rightarrow 59$ (A T0) (B T+24h), ambroxol transition $376 \rightarrow 261$ (C T0) (D T+24h), budesonide transition $521 \rightarrow 503$ (E T0) (F T+24h) a beclomethasone dipropionate transition $431 \rightarrow 413$ ( $(\mathrm{TT})$ (H T+24h). 
$\mathrm{N}$-acetylcysteine $(300 \mathrm{mg} / 3 \mathrm{ml})$, after dilution with Sirmione thermal water in ampoules for aerosol therapy. All the active drugs showed good stability under the analyzed conditions, for 24 hours at room temperature.

\section{Author contributions}

All authors contributed equally to the writing of this paper. All authors read and approved the final manuscript.

\section{References}

1. Ahrens RC (2005) The role of the MDI and DPI in pediatric patients: "Children are not just miniature adults". Respir Care 50: 1323-1328. Link: https://bit.ly/3qWWeJO

2. Bettoncelli G (2007) Criteri per l'utilizzo della terapia inalatoria nelle patologie ostruttive delle vie aeree. Rivista SIMG 5: 11-14. Link: https://bit.ly/3qYFcv5

3. Al-Subu AM, Hagen S, Eldridge M, Boriosi J (2017) Aerosol therapy through high flow nasal cannula in pediatric patients. Expert Rev Respir Med 11: 945 953. Link: https://bit.ly/3AL4O2H

4. Terzano C, Allegra L, Grassi C, Dal Negro RW, Passali S, et al. (1999) Linee guida in aerosol terapia. Giornale Italiano delle Malattie del Torace 6: 463-490. Link: https://bit.ly/36ruP9o

5. Barnes NC (2007) The properties of inhaled corticosteroids: similarities and differences. Prim Care Respir J 16: 149-154. Link: https://bit.ly/3yD2CIP

6. Fashner J, Ericson K, Werner S (2012) Treatment of the common cold in children and adults. Am Fam Physician 86: 153-159.Link: https://bit.ly/3e1clvb

7. Maselli DJ, Keyt H, Restrepo MI (2017) Inhaled Antibiotic Therapy in Chronic Respiratory Diseases. Int J Mol Sci 18: 1062. Link: https://bit.ly/3e28IA3

8. Papsin B, McTavish A (2003) Saline nasal irrigation. Its role as an adjunct treatment. Can Fam Physician 49: 168-173. Link: https://bit.ly/3dVwZCo

9. Ural A, Oktemer TK, Kizil Y, lleri F, Uslu S (2009) Impact of isotonic and hypertonic saline solutions on mucociliary activity in various nasal pathologies: clinical study. J Laryngol Otol 123: 517-521. Link: https://bit.ly/2TP5Fig

10. Amabile G, Pignataro L, Pignataro O (2000) Valutazione strumentale dell'efficacia della crenoterapia solfureo-salso-bromo-iodica nelle rinosinusiti croniche. Otorinolaringologia 50: 27-34. Link: https://bit.ly/2SYiaaV

11. Fohl AL, Johnson CE, Cober MP (2011) Stability of extemporaneously prepared acetylcysteine $1 \%$ and $10 \%$ solutions for treatment of meconium ileus. Am J Health Syst Pharm 68: 69-72. Link: https://bit.ly/3hqyyKB

12. Kiser TH, Oldland AR, Fish DN (2007) Stability of acetylcysteine solution repackaged in oral syringes and associated cost savings. Am J Health Syst Pharm 64: 762-766. Link: https://bit.ly/3htPINe

13. Trivedi RK, Patel MC, Jadhav SB (2011) A Rapid, Stability Indicating RP-UPLC Method for Simultaneous Determination of Ambroxol Hydrochloride, Cetirizine Hydrochloride and Antimicrobial Preservatives in Liquid Pharmaceutical Formulation. Scientia Pharmaceutica 79: 525-543. Link: https://bit.ly/3e0GDUf

14. Muralidharan S, Kumar JR, Dhanara SA (2013) Development and validation of an high-performance liquid chromatographic, and an ultraviolet spectrophotometric method for determination of Ambroxol hydrochloride in pharmaceutical preparations. J Adv Pharm Technol Res 4: 65-68. Link: https://bit.ly/3xG7m04
15. Hou S, Hindle M, Byron PR (2001) A stability-indicating HPLC assay method for budesonide. J Pharm Biomed Anal 24: 371-380. Link: https://bit.ly/3k1133o

16. Sambandan E, Kathavarayan T, Sellappan S, Shiea J, Ponnusamy VK (2019) Identification and characterization of unknown degradation impurities in beclomethasone dipropionate cream formulation using HPLC, ESI-MS and NMR. J Pharm Biomed Anal 167: 123-131. Link: https://bit.ly/3hNJf9m

17. Taylor RL, Grebe SK, Singh RJ (2004) Quantitative, highly sensitive liquid chromatography-tandem mass spectrometry method for detection of synthetic corticosteroids. Clin Chem 50: 2345-2352. Link: https://bit.ly/3e2iQmS

18. Norme di Buona Preparazione, Farmacopea Ufficiale Italiana XII ed (2018) Roma, Istituto Poligrafico e Zecca dello Stato.

19. Shah VP, Midha KK, Findlay JW, Hill HM, Hulse JD, et al. (2000) Bioanalytical method validation-a revisit with a decade of progress. Pharm Res 17: 15511557. Link: https://bit.ly/3wtEXcj

20. Nováková L, Vlcková H (2009) A review of current trends and advances in modern bio-analytical methods: chromatography and sample preparation. Anal Chim Acta 656: 8-35. Link: https://bit.ly/3dVNzSv

21. Thummala VR, Ivaturi MR, Nittala SR (2014) Isolation, Identification, and Characterization of One Degradation Product in Ambroxol by HPLC Hyphenated Techniques. Sci Pharm 82: 247-263. Link: https://bit.ly/3yCHOMB

Highlights

* Signatory publisher of ORCID

* Signatory Publisher of DORA (San Francisco Declaration on Research Assessment)

* Articles archived in worlds' renowned service providers such as Portico, CNKI, AGRIS, TDNet, Base (Bielefeld University Library), CrossRef, Scilit, J-Gate etc.

* Journals indexed in ICMJE, SHERPA/ROMEO, Google Scholar etc.

* OAI-PMH (Open Archives Initiative Protocol for Metadata Harvesting)

* Dedicated Editorial Board for every journal

* Accurate and rapid peer-review process

* Increased citations of published articles through promotions

* Reduced timeline for article publication

Submit your articles and experience a new surge in publication services (https://www.peertechz.com/submission).

Peertechz journals wishes everlasting success in your every endeavours.

Copyright: @ 2021 Robustelli della Cuna FS, et al. This is an open-access article distributed under the terms of the Creative Commons Attribution License, which permits unrestricted use, distribution, and reproduction in any medium, provided the original author and source are credited. 